\title{
A Phytase Characterized by Relatively High pH Tolerance and Thermostability from the Shiitake Mushroom Lentinus edodes
}

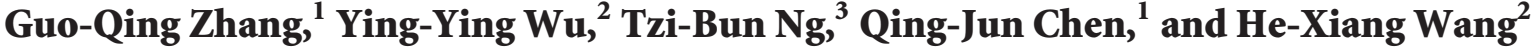 \\ ${ }^{1}$ College of Biosciences and Biotechnology, Beijing University of Agriculture, Beijing 102206, China \\ ${ }^{2}$ State Key Laboratory of Agro-Biotechnology and MOA Key Laboratory of Soil Microbiology, College of Biological Sciences, \\ China Agricultural University, Beijing 100193, China \\ ${ }^{3}$ School of Biomedical Sciences, Faculty of Medicine, The Chinese University of Hong Kong, Shatin, New Territories, Hong Kong
}

Correspondence should be addressed to He-Xiang Wang; hxwang1957@gmail.com

Received 25 November 2012; Revised 31 January 2013; Accepted 25 February 2013

Academic Editor: Chiu-Chung Young

Copyright (C) 2013 Guo-Qing Zhang et al. This is an open access article distributed under the Creative Commons Attribution License, which permits unrestricted use, distribution, and reproduction in any medium, provided the original work is properly cited.

\begin{abstract}
A monomeric phytase with a molecular mass of $14 \mathrm{kDa}$ was acquired from fresh fruiting bodies of the shiitake mushroom Lentinus edodes. The isolation procedure involved chromatography on DEAE-cellulose, CM-cellulose, Q-Sepharose, Affi-gel blue gel, and a final fast protein liquid chromatography-gel filtration on Superdex 75. The purified phytase demonstrated the unique N-terminal amino acid sequence DPKRTDQVN, which exhibited no sequence similarity with those of other phytases previously reported. It expressed its maximal activity at $\mathrm{pH} 5.0$ and $37^{\circ} \mathrm{C}$. Phytase activity manifested less than $20 \%$ change in activity over the $\mathrm{pH}$ range of 3.0-9.0, considerable thermostability with more than $60 \%$ residual activity at $70^{\circ} \mathrm{C}$, and about $40 \%$ residual activity at $95^{\circ} \mathrm{C}$. It displayed a wide substrate specificity on a variety of phosphorylated compounds with the following ranking: ATP > fructose-6phosphate $>$ AMP $>$ glucose-6-phosphate $>$ ADP $>$ sodium phytate $>\beta$-glycerophosphate. The phytase activity was moderately stimulated by $\mathrm{Ca}^{2+}$, but inhibited by $\mathrm{Al}^{3+}, \mathrm{Mn}^{2+}, \mathrm{Zn}^{2+}$, and $\mathrm{Cu}^{2+}$ at a tested concentration of $5 \mathrm{mM}$.
\end{abstract}

\section{Introduction}

Phytic acid (myo-inositol 1, 2, 3, 4, 5, 6-hexakisphosphoric acid) is the primary storage form of phosphate in plants and the prime concern for human nutrition and health management $[1,2]$. As an antinutritional component, phytic acid can strongly chelate with cations such as calcium, kalium, magnesium, iron, copper, zinc, and as well as proteins [3]. That is why phytic acid adversely affects the mineral absorption and digestion [4]. Phytate (myo-inositol 1, 2, 3, 4, 5, 6-hexakisphosphates, phytic acid) generally presented as salt of the mono- or divalent cations as $\mathrm{K}^{+}, \mathrm{Ca}^{2+}$, and $\mathrm{Mg}^{2+}$ and is widely distributed in plants, microorganisms, and some animals, and especially in seeds and nuts of plants. Although it is a main storage form of phosphate, phytate cannot be utilized by monogastric animals such as pig, poultry, and humans as they lack phytate-degrading enzymes [5].

The enzyme phytase, chemically known as myo-inositol 1 , 2, 3, 4, 5, 6-hexakisphosphate phosphohydrolase, belongs to a subclass of the family of histidine acid phosphatases (HAP). It can catalyze the sequential release of phosphate from phytate [6]. Although the first phytase was reported from rice brans in early 20th century, these enzymes are widely distributed among plant, bacteria, yeast, and fungi [7, 8]. Extensive studies conducted on microbial phytases have proved their efficacy which could be tapped for animal nutrition, human health, and environment protection purposes $[9,10]$. The first commercial phytase was produced from Aspergillus niger and was released to the market in 1991 [1]. At the end of the 20th century, the annual sale of phytase as an animal feed supplement was estimated to be about $\$ 500$ million [11]. 
Moreover, its potential in human nutritional improvement and in aquaculture has also being extensively explored [12, 13].

Lentinus edodes, commonly referred to as shiitake mushroom, is a popular edible and medicinal mushroom, which is cultivated and consumed in many Asian countries. Compounds isolated from its fruiting bodies or mycelia, such as lectin, laccase, and polysaccharide, have been demonstrated to show a variety of therapeutic properties, especially antitumor, antivirus, and immunomodulatory activities [14-16]. The present investigation was undertaken with an aim to isolate and characterize the phytase from L. edodes. The study would supplement the nutritional literature pertaining to this mushroom.

\section{Materials and Methods}

2.1. Materials and Reagents. Fresh fruiting bodies of shiitake mushroom $L$. edodes were purchased from a local market in Beijing, China. DEAE-cellulose, CM-cellulose, Tris-base, sodium phytate, AMP, ADP, ATP, fructose-6-phosphate (F6-P), glucose-6-phosphate (G-6-P), and $\beta$-glycerophosphate were obtained from Sigma, St. Louis, MO, USA. Affi-gel Blue gel was purchased from Bio-Rad, Richmond, CA, USA. QSepharose, Superdex 75 HR 10/30 column, and molecular mass standards were obtained from GE Healthcare, USA. All other reagents used were of reagent grade from China unless otherwise mentioned.

2.2. Enzyme Assay. Phytase activity was measured using a modified ferrous sulfate-molybdenum blue assay [2]. In brief, $25 \mu \mathrm{L}$ enzyme solution was incubated with $475 \mu \mathrm{L}$ of $5 \mathrm{mM}$ sodium phytate in $50 \mathrm{mM}$ Tris- $\mathrm{HCl}$ buffer $\left(\mathrm{pH} \mathrm{7.0)}\right.$ ) at $37^{\circ} \mathrm{C}$ for $15 \mathrm{~min}$. The enzyme reaction was subsequently terminated by the addition of $500 \mu \mathrm{L} 10 \%$ (w/v) trichloroacetic acid. The released phosphate was measured at $700 \mathrm{~nm}$ after adding $1000 \mu \mathrm{L}$ of freshly prepared color reagent, which was composed of $1 \%(\mathrm{w} / \mathrm{v})$ ammonium molybdate, $3.2 \%(\mathrm{v} / \mathrm{v})$ sulfuric acid solution, and $7.2 \%(\mathrm{w} / \mathrm{v})$ ferrous sulfate solution. One unit of phytase activity was defined as the amount of enzyme needed to liberate $1 \mu \mathrm{mol}$ phosphate per min under the assay conditions. Protein was determined according to Bradford using a protein assay kit (Bio-Rad Lab, Richmind, CA, USA) with bovine serum albumin as the standard [17]. All determinations were performed in triplicate.

2.3. Purification of Phytase. Fresh fruiting bodies of shiitake mushroom (2000 g) were homogenized and extracted with cold distilled water $(4 \mathrm{~mL} / \mathrm{g})$ at $4^{\circ} \mathrm{C}$ for $4 \mathrm{~h}$. Following the centrifugation at $12000 \mathrm{rpm}$ for $15 \mathrm{~min}$, the supernatant obtained was subjected to ultrafiltration until the volume was reduced to $100 \mathrm{~mL}$. $\mathrm{NH}_{4} \mathrm{HCO}_{3}$ buffer $(1 \mathrm{M}, \mathrm{pH} 9.5)$ was added until the molarity of $\mathrm{NH}_{4} \mathrm{HCO}_{3}$ attained $10 \mathrm{mM}$. Ion exchange chromatography on a DEAE-cellulose column $(2.5 \mathrm{~cm} \times$ $30 \mathrm{~cm}$ ) was conducted in $10 \mathrm{mM} \mathrm{NH}_{4} \mathrm{HCO}_{3}$ buffer $(\mathrm{pH} 9.5)$. After the removal of unadsorbed materials (fractions D1 and $\mathrm{D} 2)$, the column was washed with $1 \mathrm{M} \mathrm{NaCl}$ in the $10 \mathrm{mM}$ $\mathrm{NH}_{4} \mathrm{HCO}_{3}$ buffer ( $\mathrm{pH}$ 9.5) to remove adsorbed materials.
Fraction D2 enriched in phytase activity was dialyzed against $10 \mathrm{mM} \mathrm{NH}_{4} \mathrm{OAc}$ buffer and then subjected to ion exchange chromatography on a $2.5 \mathrm{~cm} \times 20 \mathrm{~cm}$ column of CM cellulose in $10 \mathrm{mM} \mathrm{NH}_{4} \mathrm{OAc}$ buffer ( $\mathrm{pH}$ 4.5). The unadsorbed fraction CM1 containing phytase activity was collected before the desorption of inactive adsorbed materials (collected as fraction $\mathrm{CM} 2$ ) with $10 \mathrm{mM} \mathrm{NH}_{4} \mathrm{OAc}$ buffer ( $\mathrm{pH} 4.5$ ) containing $1 \mathrm{M}$ $\mathrm{NaCl}$. Fraction CM1 was then applied on a $2.5 \mathrm{~cm} \times 20 \mathrm{~cm}$ column of Affi-gel Blue gel in $10 \mathrm{mM}$ Tris- $\mathrm{HCl}$ buffer $(\mathrm{pH}$ 7.5). Unadsorbed fraction with phytase activity (fraction B1) was eluted with the same buffer while adsorbed proteins devoid of phytase activity (fraction B2) were desorbed with $1 \mathrm{M} \mathrm{NaCl}$ added to the $10 \mathrm{mM}$ Tris- $\mathrm{HCl}$ buffer. Fraction B1 was subsequently chromatographed on a $1.0 \mathrm{~cm} \times 30 \mathrm{~cm}$ column of Q-Sepharose in $10 \mathrm{mM} \mathrm{NH}_{4} \mathrm{HCO}_{3}$ buffer ( $\left.\mathrm{pH} 9.5\right)$. Unadsorbed proteins were eluted into two fractions, Q1 and Q2, while adsorbed proteins were eluted into fraction Q3 with $1 \mathrm{M} \mathrm{NaCl}$ in the starting buffer $10 \mathrm{mM} \mathrm{NH}_{4} \mathrm{HCO}_{3}$ (pH 9.5). Fraction Q2 with phytase activity was next subjected to gel filtration by fast protein liquid chromatography (FPLC) on a Superdex $75 \mathrm{HR} 10 / 30$ column in $0.2 \mathrm{M} \mathrm{NH}_{4} \mathrm{HCO}_{3}$ buffer $(\mathrm{pH}$ 8.5) using an AKTA Purifier system (GE Healthcare, USA). The second peak (SU2) represented purified phytase.

2.4. Determination of Molecular Mass. The molecular mass of the purified phytase was determined using sodium dodecyl sulfate polyacrylamide gel electrophoresis (SDS-PAGE) and FPLC-gel filtration. In SDS-PAGE, a $12 \%$ resolving gel and a $5 \%$ stacking gel were used, with a procedure as described by Laemmli and Favre [23]. At the end of electrophoresis, the gel was stained with $0.1 \%$ Coomassie brilliant blue G-250. The molecular mass of the purified phytase was calculated using a $\lg M r$ migrate rate curve based on the molecular mass standards used in SDS-PAGE. In FPLC-gel filtration, another curve of elution volume- $\lg M r$ was obtained. The molecular mass of purified phytase was calculated using the curve and its elution volume.

2.5. Determination of N-Terminal Amino Acid Sequence. The $\mathrm{N}$-terminal sequence of the phytase was determined and carried out using an HP G1000A Edman degradation unit and an HP 1000 HPLC system.

2.6. Assay for $p H$ Optimum, Temperature Optimum, and Thermostability of Purified Phytase. A series of sodium phytate solution in buffers with different $\mathrm{pH}$ values including $50 \mathrm{mM}$ NaOAc (pH 3.0-5.0), $50 \mathrm{mM}$ Mes (pH 5.0-7.0), and $50 \mathrm{mM}$ Hepes ( $\mathrm{pH}$ 7.0-9.0) were used to determine the optimal $\mathrm{pH}$ value. For determining the optimal temperature, the reaction mixture was incubated at $20^{\circ} \mathrm{C}, 30^{\circ} \mathrm{C}, 37^{\circ} \mathrm{C}, 45^{\circ} \mathrm{C}, 50^{\circ} \mathrm{C}, 60^{\circ} \mathrm{C}$, $70^{\circ} \mathrm{C}, 80^{\circ} \mathrm{C}$, and $100^{\circ} \mathrm{C}$ in $50 \mathrm{mM} \mathrm{NaOAc}$ ( $\mathrm{pH} 5.0$ ) for $15 \mathrm{~min}$, respectively. In the thermostability assay, enzyme solutions were previously incubated at various temperatures $\left(45^{\circ} \mathrm{C}\right.$, $60^{\circ} \mathrm{C}, 70^{\circ} \mathrm{C}$, and $\left.80^{\circ} \mathrm{C}\right)$ for various durations $(10,20,40$, and $60 \mathrm{~min}$ ), respectively. The residual activity was measured using the standard assay after the enzyme solutions had been cooled down to room temperature. All determinations were performed in triplicate. 
TABLE 1: Summary of purification procedure of L. edodes phytase (from $2000 \mathrm{~g}$ fresh fruiting bodies).

\begin{tabular}{lccccc}
\hline Purification step & Yield $(\mathrm{mg})$ & ${\text { Total activity }(\mathrm{U})^{\mathrm{a}}}$ & ${\text { Specific activity }(\mathrm{U} / \mathrm{mg})^{\mathrm{b}}}^{\mathrm{b}}$ & Recovery rate $(\%)^{\text {Purification fold }^{\mathrm{c}}}$ \\
\hline Water extract & 4515.0 & 406.4 & 0.09 & 100 & 74.8 \\
DEAE cellulose & 498.2 & 303.9 & 0.61 & 54.0 & 6.8 \\
CM cellulose & 252.3 & 219.5 & 0.87 & 38.0 & 9.7 \\
Blue gel & 137.8 & 154.3 & 1.12 & 27.7 & 12.4 \\
Q-sepharose & 63.5 & 112.4 & 1.77 & 20.7 & 34.7 \\
Superdex 75 & 27.1 & 84.3 & 3.11 & & 34.6 \\
\hline
\end{tabular}

Total activity: phytase activity $(\mathrm{U} / \mathrm{mL})$ in each step $\times$ volume $(\mathrm{mL})$;

${ }^{\mathrm{b}}$ Specific activity: total activity/yield;

${ }^{c}$ Purification fold: specific activity of each step/specific activity of the first step.

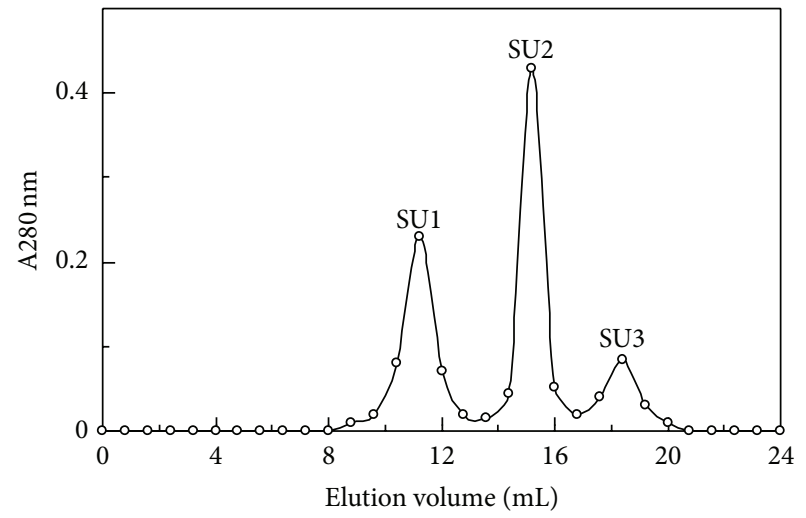

(a)

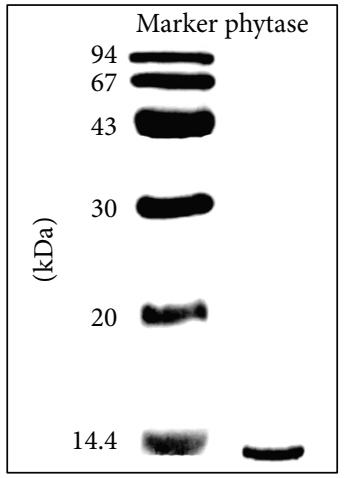

(b)

Figure 1: (a) FPLC-gel filtration on Superdex $75 \mathrm{HR} 10 / 30$ column. Eluent: $0.2 \mathrm{M} \mathrm{NH}_{4} \mathrm{HCO}_{3}$ buffer (pH 8.5). Fraction size: $0.8 \mathrm{~mL}$. Flow rate: $0.4 \mathrm{~mL} / \mathrm{min}$. Fraction SU2 represents purified phytase. (b) SDS-PAGE of fraction SU2.

TABLE 2: Characteristics of L. edodes phytase with other fungal phytases.

\begin{tabular}{|c|c|c|c|c|c|}
\hline Species & Amino acid sequence & Chromatography behavior & $\begin{array}{l}\text { Molecular } \\
\text { mass }(\mathrm{kDa})\end{array}$ & $\underset{\text { optimum }}{\mathrm{pH}}$ & $\begin{array}{c}\text { Temperature } \\
\text { optimum } \\
\left({ }^{\circ} \mathrm{C}\right)\end{array}$ \\
\hline L. edodes (this study) & 1 DPKRTDQVN 9 & $\begin{array}{l}\text { Unadsorbed on DEAE-cellulose, } \\
\text { CM-cellulose, blue gel, and } \\
\text { Q-Sepharose }\end{array}$ & 14 & 5.0 & 37 \\
\hline Flammulina velutipes [18] & $1 \underline{\mathrm{DF}} \mathrm{FVDTG} \underline{\mathbf{N N}} 10$ & $\begin{array}{l}\text { Adsorbed on DEAE-cellulose and } \\
\text { Q-Sepharose; unadsorbed on } \\
\text { CM-cellulose and Blue gel }\end{array}$ & 14.8 & 5.0 & 45 \\
\hline Volvariella volvacea [19] & 1 GEDNEHDTQA 10 & $\begin{array}{l}\text { Adsorbed on Q-Sepharose; } \\
\text { unadsorbed on DEAE-cellulose, } \\
\text { CM-cellulose, and Blue gel }\end{array}$ & 14 & 5.0 & 45 \\
\hline $\begin{array}{l}\text { Aspergillus niger (PhyA) } \\
{[8,20,21](\mathrm{emb}:} \\
\text { CAA78904.1) }\end{array}$ & 218 DSELADT TEE 227 & - & 85 & $2.5,5.0$ & 58 \\
\hline $\begin{array}{l}\text { A. niger }(\mathrm{PhyB})[8,22] \\
\text { (pdb:1QFX) }\end{array}$ & $46 \underline{\text { DPPTSCEVDQVI } 57}$ & - & $85-100$ & 2.5 & 60 \\
\hline A. ficcum (PhyB) [2] & $46 \underline{\text { DPPTSCEVDQVI } 57}$ & $\begin{array}{l}\text { Adsorbed on DEAE-cellulose and } \\
\text { CM-cellulose }\end{array}$ & 65.5 & 1.3 & 67 \\
\hline $\begin{array}{l}\text { Kodamaea ohmeri }[1,2] \\
(\mathrm{ABU} 53001.1)\end{array}$ & 24 TPEQAAVEQYY $\underline{\mathbf{N}} 34$ & Adsorbed on DEAE sepharose & 98.2 & 5.0 & 65 \\
\hline
\end{tabular}

-: no data available. Sequence analysis using DNAMAN V6.0.3.99.

Amino acid residues identical to corresponding residues of $L$. edodes phytase are underlined. 


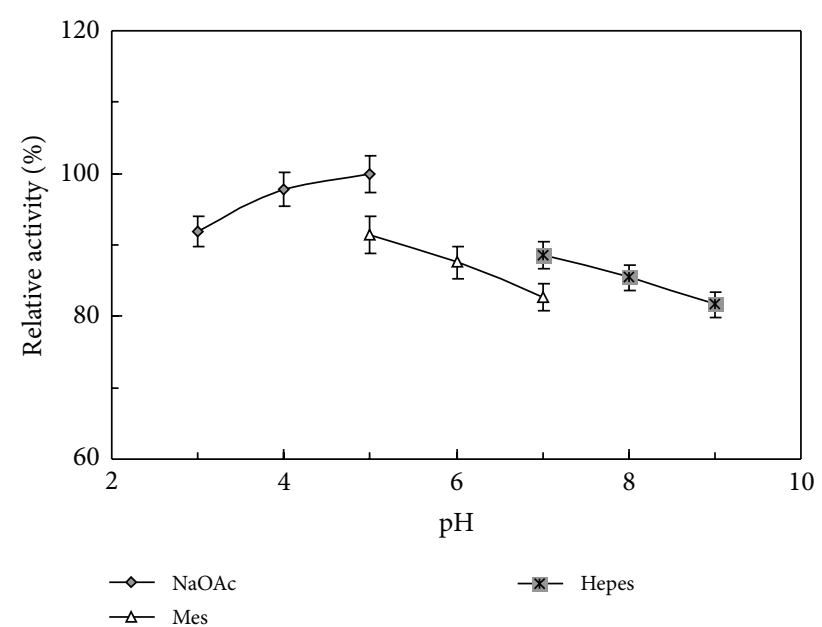

FIGURE 2: Effect of $\mathrm{pH}$ on activity of the purified L. edodes phytase. Maximal phytase activity at $\mathrm{pH}$ optimum was defined as $100 \%$. Results are presented as mean $\pm \mathrm{SD}(n=3)$.

TABLE 3: Substrate specificity of L. edodes phytase.

\begin{tabular}{lc}
\hline Substrate & Relative activity (\%) \\
\hline Sodiumm phytate & $100.0 \pm 5.1$ \\
$\beta$-glycerophosphate & $98.5 \pm 3.7$ \\
ADP & $103.4 \pm 6.2$ \\
G-6-P & $127.9 \pm 3.9$ \\
AMP & $143.8 \pm 7.0$ \\
F-6-P & $158.2 \pm 4.6$ \\
ATP & $208.1 \pm 6.4$ \\
\hline
\end{tabular}

The phytase activity towards sodium phytate $(5.0 \mathrm{mM})$ was regarded as $100 \%$. Phytase activity was assayed with increasing concentration of Pi using the standard phytase assay. Results are presented as mean $\pm \mathrm{SD}(n=3)$.

TABLE 4: Effects of metal ions and EDTA on phytase activity.

\begin{tabular}{lcc}
\hline & \multicolumn{2}{c}{ Relative activity (\%) } \\
& $1 \mathrm{mM}$ & $5 \mathrm{mM}$ \\
\hline $\mathrm{K}^{+}$ & $101.5 \pm 3.2$ & $104.9 \pm 2.8$ \\
$\mathrm{Ca}^{2+}$ & $107.6 \pm 3.1$ & $114.8 \pm 5.3$ \\
$\mathrm{Mg}^{2+}$ & $102.7 \pm 0.8$ & $103.5 \pm 3.5$ \\
$\mathrm{Mn}^{2+}$ & $95.4 \pm 5.1$ & $69.6 \pm 2.7$ \\
$\mathrm{Zn}^{2+}$ & $90.2 \pm 2.1$ & $76.5 \pm 1.6$ \\
$\mathrm{Cu}^{2+}$ & $104.6 \pm 2.5$ & $82.8 \pm 2.3$ \\
$\mathrm{Fe}^{3+}$ & $96.9 \pm 3.0$ & $100.2 \pm 1.7$ \\
$\mathrm{Al}^{3+}$ & $67.6 \pm 1.3$ & $32.5 \pm 0.9$ \\
EDTA & $100.7 \pm 2.8$ & $103.4 \pm 2.3$ \\
\hline
\end{tabular}

The phytase activity in the absence of metal ions was regarded as $100 \%$. Data are given as means $\pm \mathrm{SD}, n=3$.

2.7. Assay for Substrate Specificity. In order to determine the substrate specificity of the purified phytase, several phosphorylated substrates instead of sodium phytate, all at $5 \mathrm{mM}$ concentrations, were added to the assay solution. They included AMP, ADP, ATP, fructose-6-phosphate, glucose6-phosphate, and $\beta$-glycerophosphate. The buffer used was

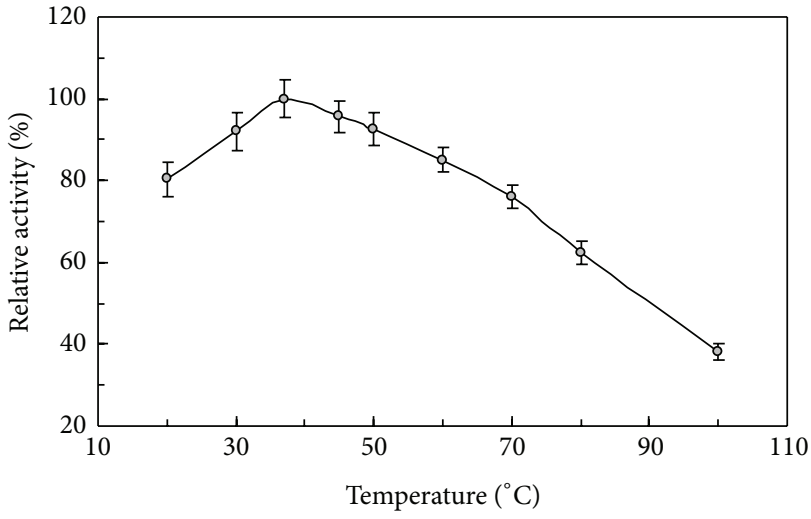

FIGURE 3: Effect of temperature on activity of the purified L. edodes phytase. Maximal phytase activity at temperature optimum was defined as $100 \%$. Results are presented as mean \pm SD $(n=3)$.

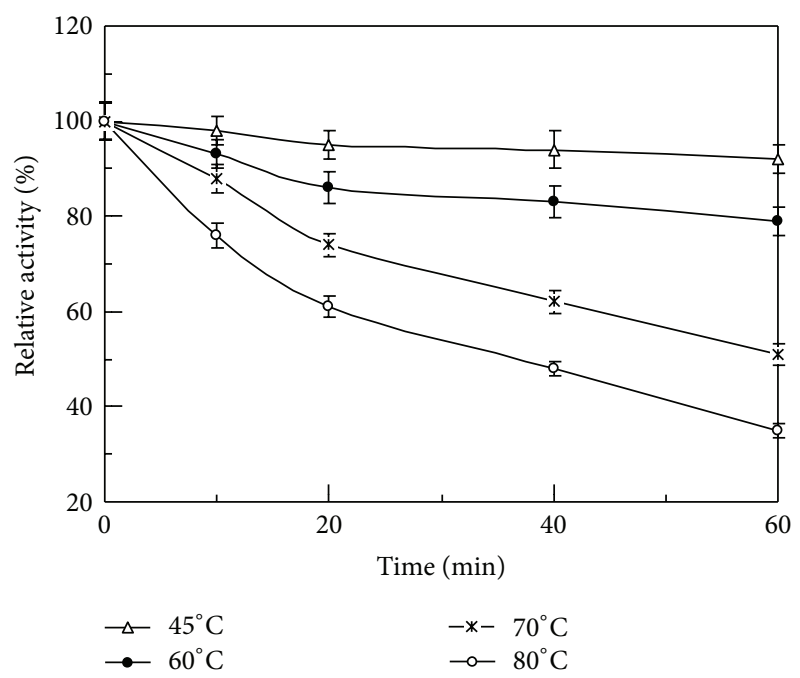

FIgURE 4: Thermostability of the purified L. edodes phytase. Phytase activity at 0 min was defined as $100 \%$. Results are presented as mean $\pm \mathrm{SD}(n=3)$.

$50 \mathrm{mM} \mathrm{NaOAc}(\mathrm{pH}$ 5.0). The release of Pi was determined as mentioned above.

2.8. Effects of Metal Ions and EDTA on Phytase Activity. Equal volumes $(25 \mu \mathrm{L})$ of metal ions or EDTA (with a final concentration of $1 \mathrm{mM}$ and $5 \mathrm{mM}$ ) were mixed with the purified phytase solution in $50 \mathrm{mM} \mathrm{NaOAc}$ buffer ( $\mathrm{pH}$ 5.0) for $2 \mathrm{~h}$ at $4^{\circ} \mathrm{C}$ before the standard phytase assay was performed. The activity assayed in the absence of metal ions was defined as the control. The metal ions tested include $\mathrm{K}^{+}$, $\mathrm{Ca}^{2+}, \mathrm{Mg}^{2+}, \mathrm{Mn}^{2+}, \mathrm{Zn}^{2+}, \mathrm{Cu}^{2+}, \mathrm{Fe}^{3+}$, and $\mathrm{Al}^{3+}$.

\section{Results}

3.1. Isolation of Phytase. L. edodes phytase was purified by utilizing an isolation protocol that included one step of extraction with distilled water, three unsuccessive steps 
of ion-exchange chromatography on DEAE-cellulose, CMcellulose, and Q-Sepharose, an affinity chromatography step on, and one final step of FPLC on a Superdex 75 column. Chromatographic details including yield, recovery rate, and purification fold are presented in Table 1. L. edodes phytase was adsorbed neither on the three ion-exchange gel nor on Affi-gel blue gel. The fraction with phytase activity from the penultimate step was finally separated into three peaks on Superdex 75 (Figure 1(a)). The second and highest peak (SU2) was the purified phytase with a molecular mass of $14 \mathrm{kDa}$ based on its elution volume on FPLC-gel filtration. The enzyme was purified 34.6-fold from the crude extract with $20.7 \%$ yield. The purified phytase exhibited an activity of $3.11 \mathrm{U} / \mathrm{mg}$. Fraction SU2 subsequently appeared as a single $14 \mathrm{kDa}$ band in SDS-PAGE (Figure 1(b)). Based on the results of FPLC and SDS-PAGE, the purified phytase was a monomeric protein with a molecular mass of $14 \mathrm{kDa}$.

3.2. Properties of L. edodes Phytase. The N-terminal sequence of the purified phytase was DPKRTDQVN. A comparison of the characteristics of $L$. edodes phytase and other fungal phytases is presented in Table 2. The purified phytase expressed its maximal sodium phytate degradative activity at $\mathrm{pH} 5.0$ (Figure 2) and $37^{\circ} \mathrm{C}$ (Figure 3). It manifested less than $20 \%$ fluctuation in activity over the $\mathrm{pH}$ range of 3.0-9.0. When the assay temperature was increased from $20^{\circ} \mathrm{C}$ to $37^{\circ} \mathrm{C}$, the phytase reached its maximum degradative activity. It underwent a continuous decline in enzyme activity when the temperature was elevated further from $37^{\circ} \mathrm{C}$ to $95^{\circ} \mathrm{C}$. More than $60 \%$ phytase activity remained when it was assayed at $70^{\circ} \mathrm{C}$. About $40 \%$ residual activity can be measured when it was assayed at $95^{\circ} \mathrm{C}$. The purified phytase was fairly thermostable with less than $10 \%$ activity loss for $60 \mathrm{~min}$ incubation at $45^{\circ} \mathrm{C}$, and about $20 \%$ activity loss for $60 \mathrm{~min}$ incubation at $60^{\circ} \mathrm{C}$ (Figure 4). L. edodes phytase demonstrated a wide substrate specificity on a variety of phosphorylated compounds with the following ranking: ATP > F-6-P > AMP > G-6-P > $\mathrm{ADP}>$ sodium phytate $>\beta$-glycerophosphate (Table 3 ). The phytase activity was moderately stimulated by $\mathrm{Ca}^{2+}$ at a tested concentration of $5 \mathrm{mM}$, and not significantly affected by $\mathrm{K}^{+}, \mathrm{Ca}^{2+}, \mathrm{Mg}^{2+}, \mathrm{Mn}^{2+}, \mathrm{Cu}^{2+}, \mathrm{Fe}^{3+}$, and EDTA at a tested concentration of $1 \mathrm{mM}$, and $\mathrm{K}^{+}, \mathrm{Mg}^{2+}, \mathrm{Fe}^{3+}$, and EDTA at a tested concentration of $5 \mathrm{mM}$. Furthermore, the phytase was moderately inhibited by $\mathrm{Al}^{3+}, \mathrm{Mn}^{2+}, \mathrm{Zn}^{2+}$, and $\mathrm{Cu}^{2+}$ at a tested concentration of $5 \mathrm{mM}$ (Table 4 ).

\section{Discussion}

The shiitake mushroom is the second most popular edible mushroom in the global market and has long been considered a medicinal mushroom as well as a delicacy in Asian countries [24]. It is one of the most nutritious and medicinal mushrooms with potential therapeutic applications involving cancers, flu, heart diseases, hypertension, diabetes, antiageing, obesity, sexual dysfunction, and so on [25]. Phytase is commercially utilized to maximize phytate degradation in diet and to decrease phosphorus levels in poultry and swine manure. Extensive studies on microbial phytases especially from genus Aspergillus have been reported involving isolation, properties, fermentation, cloning, expression, structure, and so forth $[6,9,26]$. There is a dearth of literature on mushroom phytases. Collopy and Royse observed that the fruiting bodies of four edible mushroom, Agaricus bisporus, Grifola frondosa, Pleurotus cornucopiae, and L. edodes, manifested phytase activity although no details on phytase purification were reported [27]. In the present study, we focused on L. edodes phytase which played a very important role in digestion and utilization of dietary phosphorus.

During the course of isolation, L. edodes phytase was unadsorbed on all ion-exchangers and affinity chromatography media employed including DEAE-cellulose, CMcellulose, Q-Sepharose, and Affi-gel blue gel. Compared with L. edodes phytase, Volvariella volvacea phytase showed an analogous chromatographic behavior, in wich it was adsorbed on Q-Sepharose, but unadsorbed on DEAE-cellulose, CMcellulose, and Affi-gel blue gel [19]. On the other hand, Aspergillus ficcum phytase was adsorbed on both DEAEcellulose and CM-cellulose [2]. Flammulina velutipes phytase was adsorbed on DEAE-cellulose and Q-Sepharose, but unadsorbed on CM-cellulose and Affi-gel blue gel [18].

L. edodes phytase was a monomeric protein with a molecular mass of $14 \mathrm{kDa}$ based on the results of FPLC and SDSPAGE, which were very similar to phytases from $V$. volvacea $(14 \mathrm{kDa})$ [19] and F. velutipes $(14.8 \mathrm{kDa})$ [18]. Molecular masses from phytases of the genus Aspergillus fell within the range of $60-120 \mathrm{kDa}$. Phytases from bacteria such as Bacillus subtilis and Escherichia coli demonstrated molecular masses in the proximity of $40 \mathrm{kDa}$. On the other hand, plant phytases showed a wide molecular masses range from $60 \mathrm{kDa}$ (characteristic of Spelt, a kind of wheat) to $3699 \mathrm{kDa}$ (characteristic of Lilium longiflorum) [26]. Based on the protein blast search result of the $\mathrm{N}$-terminal amino acid sequence (http://blast.ncbi.nlm.nih.gov/Blast.cgi), L. edodes phytase demonstrated no sequence similarity to other phytases. At the same time, it manifested high sequence homology with a nucleoside-diphosphate-sugar epimerase from Synechococcus sp. (YP_001227174.1) and a signal transduction histidine kinase from Kytococcus sedentarius (YP_003150103.1) both of which are phosphorus transportation enzymes.

The optimal $\mathrm{pH}$ for shiitake mushroom phytase was $\mathrm{pH}$ 5.0 , with less than $20 \%$ variation in activity detected in the $\mathrm{pH}$ range of 3.0-9.0. The phytase demonstrates considerable $\mathrm{pH}$ adaptability compared with other phytases reported. Two kinds of phytases (PhyA and PhyB) were isolated from $A$. niger. A. niger PhyA exhibited two $\mathrm{pH}$ optima at $\mathrm{pH} 2.5$ and $\mathrm{pH} 5.0$, while $A$. niger $\mathrm{PhyB}$ demonstrated only a single $\mathrm{pH}$ optimum at $\mathrm{pH} 2.5$ [8]. Another PhyB from A. ficcum manifested a $\mathrm{pH}$ optimum at $\mathrm{pH} 1.3$, the lowest among all the phytases reported [2]. All three phytases showed highly $\mathrm{pH}-$ dependent enzyme activity. A. ficcum phytase lost virtually its whole activity when the ambient $\mathrm{pH}$ value reached 5.0 [2]. On the other hand, mushroom phytases from $V$. volvacea [19] and F. velutipes [18] possessed the same $\mathrm{pH}$ optimum at $\mathrm{pH} 5.0$, and also considerably stability over the $\mathrm{pH}$ range of 3.0-9.0. According to the results, the three mushroom phytases (L. edodes, V. volvacea, and F. velutipes) manifested a better $\mathrm{pH}$ tolerance than commercial Aspergillus phytases. 
Although shared similar characteristics in molecular mass and optimal $\mathrm{pH}$ value, the three mushroom phytases showed very low $\mathrm{N}$-terminal amino acid sequence similarity and different chromatography behavior.

The purified phytase required a low temperature optimum of $37^{\circ} \mathrm{C}$, which was the same as the body temperature in humans, but lower than those of other phytases reported [26]. Most of them had a temperature optimum in a temperature range of $45-70^{\circ} \mathrm{C}$ including $V$. volvacea $\left(45^{\circ} \mathrm{C}\right)$ [19], F. velutipes $\left(45^{\circ} \mathrm{C}\right)[18]$, A. niger PhyA $\left(58^{\circ} \mathrm{C}\right)[20]$, A. niger PhyB $\left(60^{\circ} \mathrm{C}\right)$ [22], A. ficcum PhyB ( $\left.65^{\circ} \mathrm{C}\right)$ [2], and Schwanniomyces castellii $\left(77^{\circ} \mathrm{C}\right)[28]$. L. edodes phytase also demonstrated considerable thermostability with about $60 \%$ residual activity at $70^{\circ} \mathrm{C}$ and $40 \%$ residual activity at $95^{\circ} \mathrm{C}$. A. ficcum PhyB was relatively stable at $60^{\circ} \mathrm{C}$ with $14 \%$ loss in activity after exposure to the temperature for $60 \mathrm{~min}$, while only about $50 \%$ of the highest enzyme activity was retained at $37^{\circ} \mathrm{C}$ [2]. The purified phytase manifested the desirable features of relative $\mathrm{pH}$ tolerance and thermostability, which makes it a promising candidate with more potential applications.

Phytase from shiitake mushroom exhibited broad substrate specificity on a range of phosphorylated compounds. $A$. niger PhyB has been reported to have a wider substrate specificity than $A$. niger phyA. A. niger phyA showed the highest activity towards sodium phytate, but very low activity towards other substrates such as F-6-P, G-6-P, and ADP. A. niger phyB had an activity toward F-1, 6-P which was 20 times higher than that towards sodium phytate [26]. The enzyme activity of $L$. edodes phytase was the highest towards ATP, like phytases from A. ficcum PhyB [2], V. volvacea [19], F. velutipes [18], and Spelt [26]. $\rho$-nitrophenyl phosphate and F1, 6-P formed the optimal substrates of A. fumigatus phytase, followed by ATP. On the other hand, alkaline phytases from B. subtilis, B. subtilis natto, B. amyloliquefaciens, and Typa latifolia had narrow substrate specificity and can use sodium phytate as their sole substrate [26].

The phytase activity was moderately stimulated by $\mathrm{Ca}^{2+}$ at a concentration of $5 \mathrm{mM}$, and not significantly affected by $\mathrm{K}^{+}, \mathrm{Ca}^{2+}, \mathrm{Mg}^{2+}, \mathrm{Mn}^{2+}, \mathrm{Cu}^{2+}, \mathrm{Fe}^{3+}$, and EDTA at a low concentration of $1 \mathrm{mM}$, but moderately inhibited by $\mathrm{Al}^{3+}, \mathrm{Mn}^{2+}, \mathrm{Zn}^{2+}$, and $\mathrm{Cu}^{2+}$ at a higher concentration of $5 \mathrm{mM}$. It was previously reported that $\mathrm{Ca}^{2+}$ had a moderately inhibitory effect on phytases from Cladosporium sp. [29], A. niger [30], and Klebsiella pneumoniae [31]. On the other hand, $\mathrm{Ca}^{2+}$ showed no significant effect on the phytase from $A$. ficcum [2]. Chelating reagents such as EDTA did not have any inhibitory effect at a concentration of $5 \mathrm{mM}$, just like other phytases from Candida krusei [32] and K. pneumoniae [31], but different from a bacterial phytate from Bacillus sp. which is strongly inhibited by EDTA at a low concentration of $1 \mathrm{mM}$ [33]. On the contrary, $10 \mathrm{mM}$ EDTA stimulated the activity of fungal phytases from A. ficcum [2] and A. fumigatus [34].

To recapitulate, L. edodes phytase displayed some characteristics distinct from those of animal, plant, bacterial, fungal, and mushroom phytases previously reported in the literature. It manifested the advantageous properties of $\mathrm{pH}$ tolerance and thermostability. It signifies that the shiitake phytase has a great potential for commercial interest as an animal feed additive or dietary adjuvant.

\section{Acknowledgments}

This work was financially supported by National Grants of China (31200070, 2010CB732202, and 2012BAD14B09) and Beijing Innovative Grant of Modern Agricultural Technology System.

\section{References}

[1] V. Kumar, A. K. Sinha, H. P. S. Makkar, and K. Becker, "Dietary roles of phytate and phytase in human nutrition: a review," Food Chemistry, vol. 120, no. 4, pp. 945-959, 2010.

[2] G. Q. Zhang, X. F. Dong, Z. H. Wang, Q. Zhang, H. X. Wang, and J. M. Tong, "Purification, characterization, and cloning of a novel phytase with low $\mathrm{pH}$ optimum and strong proteolysis resistance from Aspergillus ficuum NTG-23," Bioresource Technology, vol. 101, no. 11, pp. 4125-4131, 2010.

[3] H. Luo, H. Huang, P. Yang et al., "A novel phytase appA from Citrobacter amalonaticus CGMCC 1696: gene cloning and overexpression in Pichia pastoris," Current Microbiology, vol. 55, no. 3, pp. 185-192, 2007.

[4] V. Raboy, “myo-Inositol-1,2,3,4,5,6-hexakisphosphate," Phytochemistry, vol. 64, no. 6, pp. 1033-1043, 2003.

[5] X. G. Lei and J. M. Porres, "Phytase enzymology, applications, and biotechnology," Biotechnology Letters, vol. 25, no. 21, pp. 1787-1794, 2003.

[6] S. Haefner, A. Knietsch, E. Scholten, J. Braun, M. Lohscheidt, and O.Zelder, "Biotechnological production and applications of phytases," Applied Microbiology and Biotechnology, vol. 68, no. 5, pp. 588-597, 2005.

[7] U. Suzuki, K. Yoshimura, and M. Takaishi, "About the enzyme "phytase", which splits "anhydro-oxy-methylene diphosphoric acid," Bulletin of the College of Agriculture, Tokyo Imperial University, vol. 7, pp. 503-512, 1907.

[8] E. J. Mullaney, C. B. Daly, and A. H. J. Ullah, "Advances in phytase research," Advances in Applied Microbiology, vol. 47, pp. 157-199, 2000.

[9] A. Pandey, G. Szakacs, C. R. Soccol, J. A. Rodriguez-Leon, and V. T. Soccol, "Production, purification and properties of microbial phytases," Bioresource Technology, vol. 77, no. 3, pp. 203-214, 2001.

[10] A. Vohra and T. Satyanarayana, "Phytases: microbial sources, production, purification, and potential biotechnological applications," Critical Reviews in Biotechnology, vol. 23, no. 1, pp. 2960, 2003.

[11] P. H. Abelson, "A potential phosphate crisis," Science, vol. 283, no. 5410, p. 2015, 1999.

[12] G. Y. Yoo, X. Wang, S. Choi, K. Han, J. C. Kang, and S. C. Bai, "Dietary microbial phytase increased the phosphorus digestibility in juvenile Korean rockfish Sebastes schlegeli fed diets containing soybean meal," Aquaculture, vol. 243, no. 1-4, pp. 315-322, 2005.

[13] L. G. Da Silva, L. C. Trugo, S. Da Costa Terzi, and S. Couri, "Low phytate lupin flour based biomass obtained by fermentation with a mutant of Aspergillus niger," Process Biochemistry, vol. 40, no. 2, pp. 951-954, 2005. 
[14] O. M. Tsivileva, V. E. Nikitina, and E. A. Loshchinina, "Isolation and characterization of Lentinus edodes (Berk.) singer extracellular lectins," Biochemistry, vol. 73, no. 10, pp. 1154-1161, 2008.

[15] P. V. Jeurink, C. L. Noguera, H. F. J. Savelkoul, and H. J. Wichers, "Immunomodulatory capacity of fungal proteins on the cytokine production of human peripheral blood mononuclear cells," International Immunopharmacology, vol. 8, no. 8, pp. 1124-1133, 2008.

[16] V. P. Rincao, K. A. Yamamoto, N. M. Ricardo et al., "Polysaccharide and extracts from Lentinula edodes: structural features and antiviral activity," Virology Journal, vol. 9, article 37, 2012.

[17] E. Harlow and D. Lane, "Bradford assay," CSH Protocols, vol. 2006, no. 6, 2006.

[18] M. J. Zhu, H. X. Wang, and T. B. Ng, "Purification and identification of a phytase from fruity bodies of the winter mushroom, Flammulina velutipes," African Journal of Biotechnology, vol. 10, no. 77, pp. 17845-17852, 2011.

[19] L. Xu, G. Zhang, H. Wang, and T. B. Ng, "Purification and characterization of phytase with a wide $\mathrm{pH}$ adaptation from common edible mushroom Volvariella volvacea (Straw mushroom)," Indian Journal of Biochemistry \& Biophysics, vol. 49, no. 1, pp. 49-54, 2012.

[20] A. H. Ullah, "Aspergillus ficuum phytase: partial primary structure, substrate selectivity, and kinetic characterization," Preparative Biochemistry, vol. 18, no. 4, pp. 459-471, 1988.

[21] A. H. Ullah and D. M. Gibson, "Extracellular phytase (E.C. 3.1.3.8) from Aspergillus ficuum NRRL 3135: purification and characterization," Preparative Biochemistry, vol. 17, no. 1, pp. 6391, 1987.

[22] A. H. J. Ullah and B. Q. Phillippy, "Substrate selectivity in Aspergillus ficuum phytase and acid phosphatases using myoinositol phosphates," Journal of Agricultural and Food Chemistry, vol. 42, no. 2, pp. 423-425, 1994.

[23] U. K. Laemmli and M. Favre, "Maturation of the head of bacteriophage T4. I. DNA packaging events," Journal of Molecular Biology, vol. 80, no. 4, pp. 575-599, 1973.

[24] P. S. Bisen, R. K. Baghel, B. S. Sanodiya, G. S. Thakur, and G. B. K. S. Prasad, "Lentinus edodes: a macrofungus with pharmacological activities," Current Medicinal Chemistry, vol. 17, no. 22, pp. 2419-2430, 2010.

[25] W. Breene, "Nutritional and medicinal value of specialty mushrooms," Journal of Food Protection, vol. 53, no. 10, pp. 883-994, 1990.

[26] B. C. Oh, W. C. Choi, S. Park, Y. O. Kim, and T. K. Oh, "Biochemical properties and substrate specificities of alkaline and histidine acid phytases," Applied Microbiology and Biotechnology, vol. 63, no. 4, pp. 362-372, 2004.

[27] P. D. Collopy and D. J. Royse, "Characterization of phytase activity from cultivated edible mushrooms and their production substrates," Journal of Agricultural and Food Chemistry, vol. 52, no. 25, pp. 7518-7524, 2004.

[28] L. Segueilha, C. Lambrechts, H. Boze, G. Moulin, and P. Galzy, "Purification and properties of the Phytase from Schwanniomyces castellii," Journal of Fermentation and Bioengineering, vol. 74, no. 1, pp. 7-11, 1992.

[29] C. S. Quan, W. J. Tian, S. D. Fan, and J. I. Kikuchi, "Purification and properties of a low-molecular-weight phytase from Cladosporium sp. FP-1," Journal of Bioscience and Bioengineering, vol. 97, no. 4, pp. 260-266, 2004.

[30] A. Casey and G. Walsh, "Purification and characterization of extracellular phytase from Aspergillus niger ATCC 9142," Bioresource Technology, vol. 86, no. 2, pp. 183-188, 2003.
[31] L. Escobin-Mopera, M. Ohtani, S. Sekiguchi et al., "Purification and characterization of phytase from Klebsiella pneumoniae 93B," Journal of Bioscience and Bioengineering, vol. 113, no. 5, pp. 562-567, 2012.

[32] C. S. Quan, S. D. Fan, L. H. Zhang, Y. J. Wang, and Y. Ohta, "Purification and properties of a phytase from Candida krusei WZ-001," Journal of Bioscience and Bioengineering, vol. 94, no. 5, pp. 419-425, 2002.

[33] Y. O. Kim, H. K. Kim, K. S. Bae, J. H. Yu, and T. K. Oh, "Purification and properties of a thermostable phytase from Bacillus sp. DS11," Enzyme and Microbial Technology, vol. 22, no. 1, pp. 2-7, 1998.

[34] M. Wyss, R. Brugger, A. Kronenberger et al., "Biochemical characterization of fungal phytases (myo-inositol hexakisphosphate phosphohydrolases): catalytic properties," Applied and Environmental Microbiology, vol. 65, no. 2, pp. 367-373, 1999. 

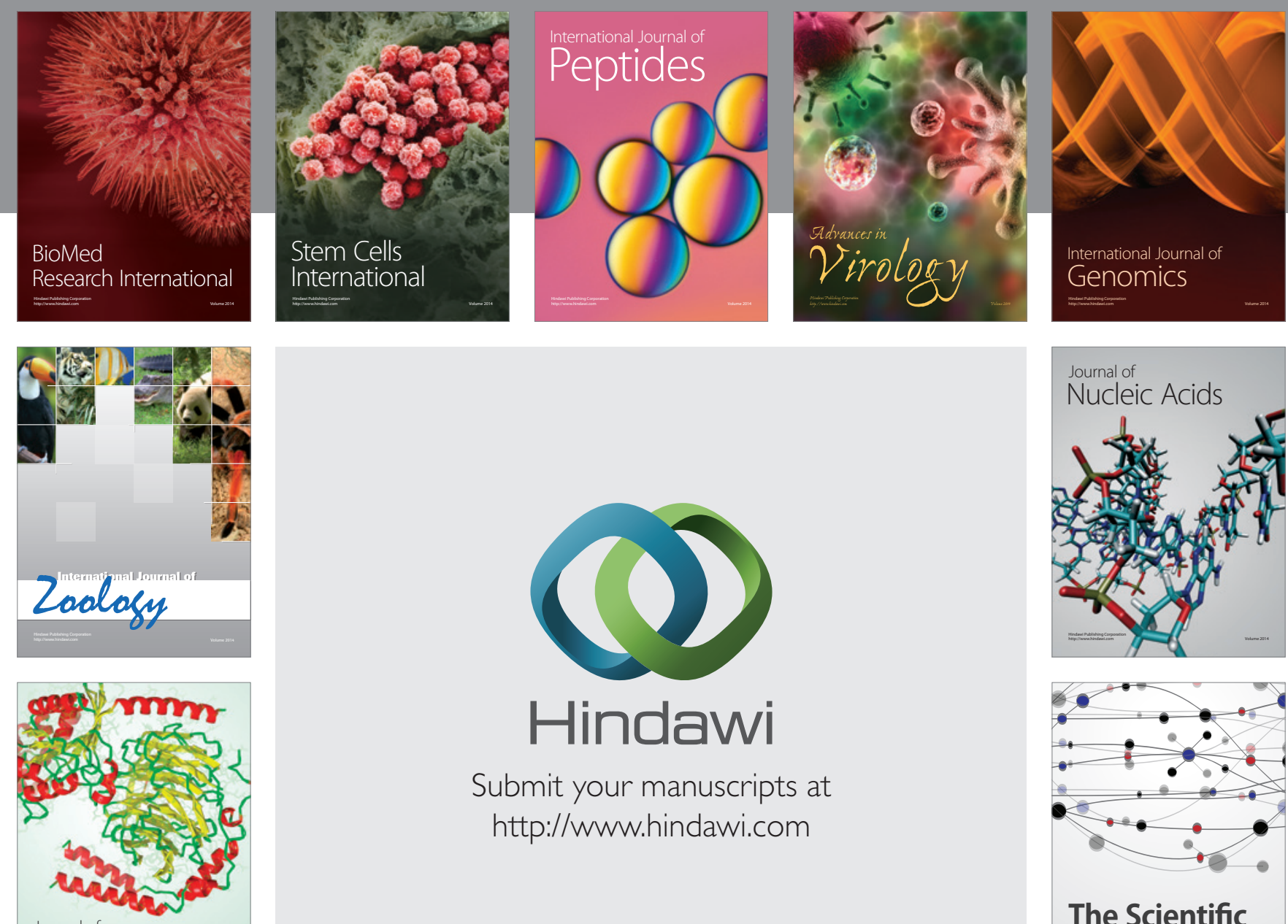

Submit your manuscripts at

http://www.hindawi.com

Journal of
Signal Transduction
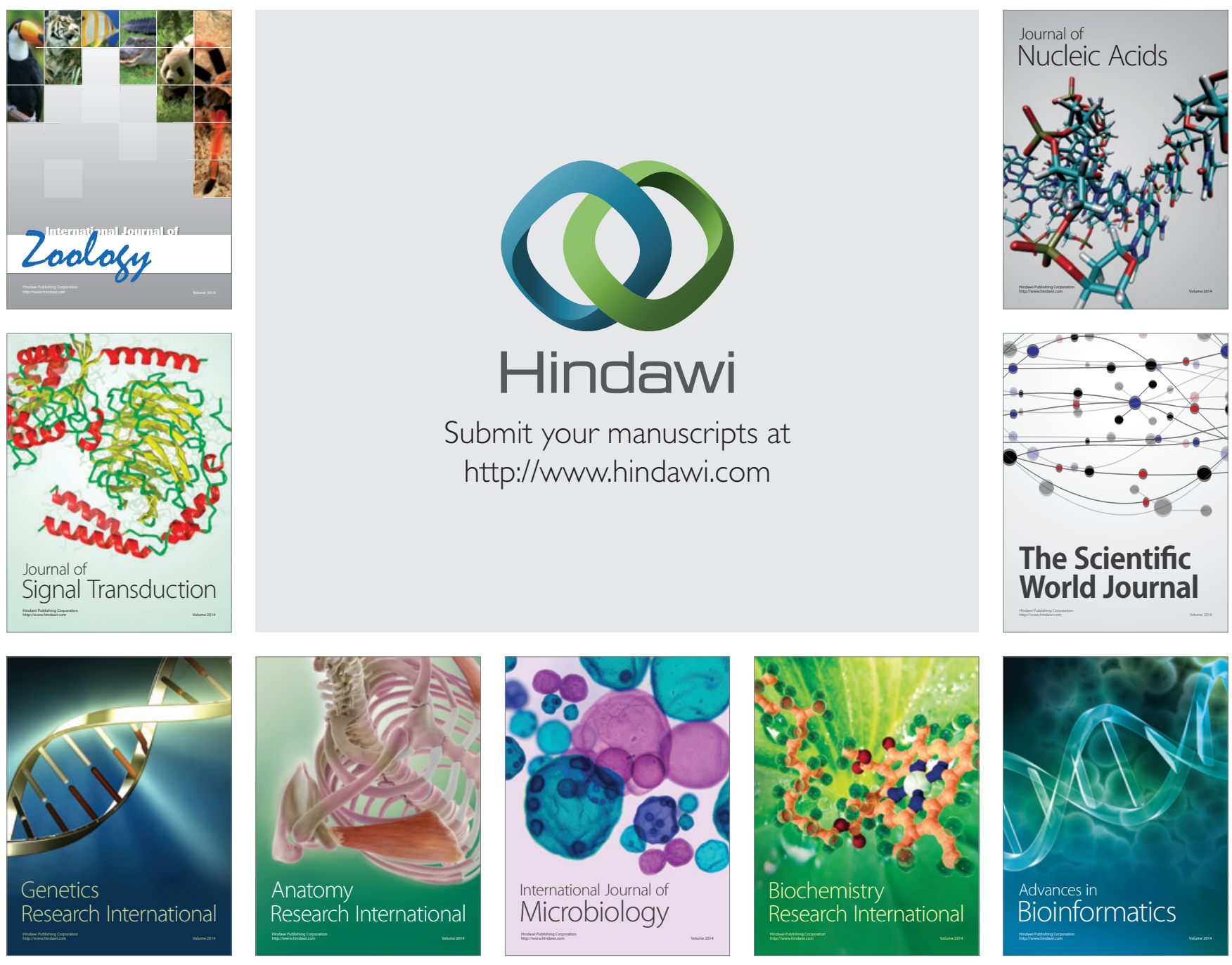

The Scientific World Journal
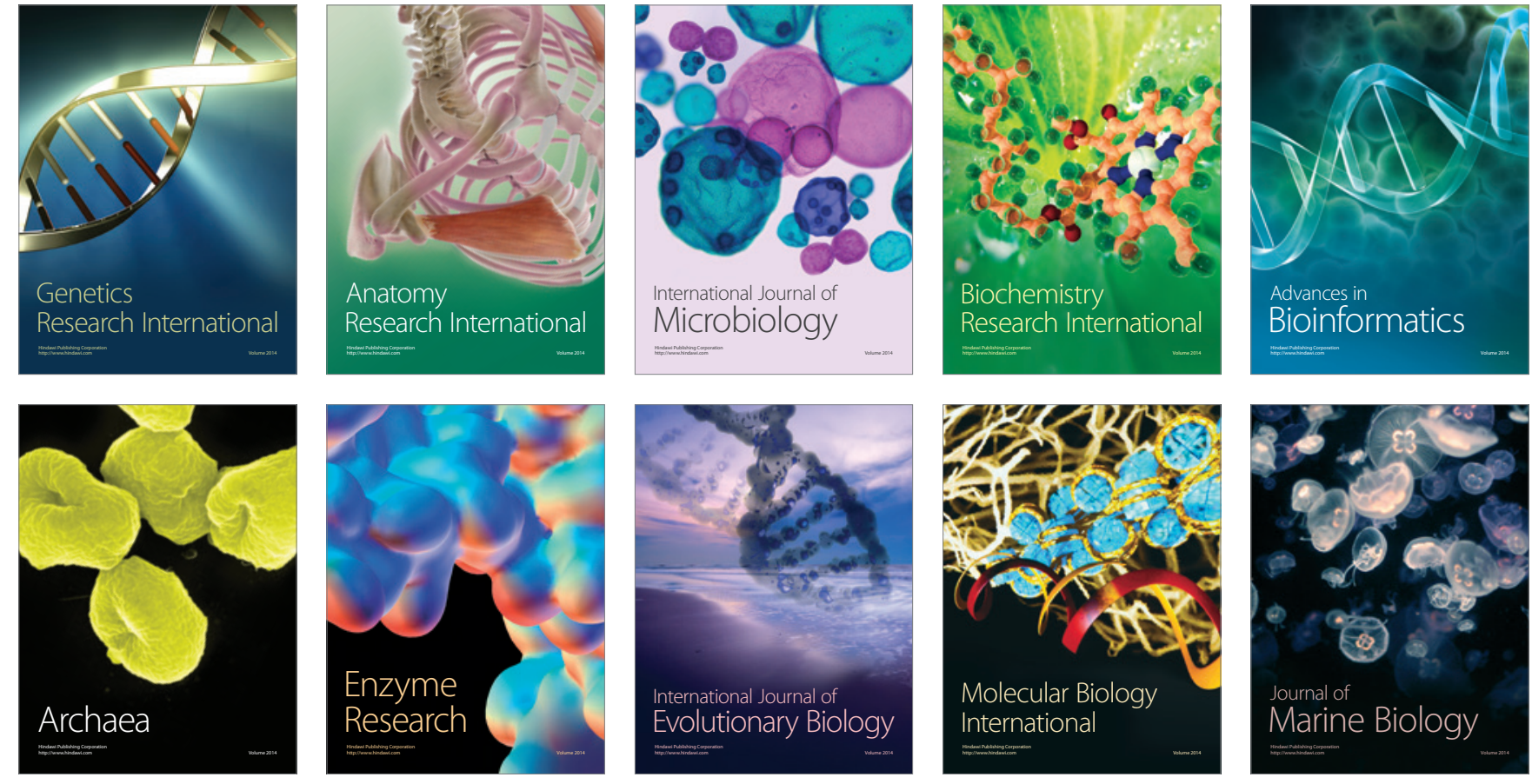